\title{
DAYA TERIMA DAN ANALISIS ZAT GIZI PADA PEMPEK SUBSTITUSI TEPUNG MOCAF
}

\author{
Cici Cutyanti, Betty Yosephin Simanjuntak, Afriyana Siregar
}

\author{
Politeknik Kesehatan Kementerian Kesehatan Bengkulu, Program Studi DIII Gizi, \\ Jalan Indragiri Nomor 3 Padang Harapan Bengkulu \\ jmkbengkulu@yahoo.com
}

\begin{abstract}
Abstrack :Mocaf flour is a flour made from cassava root (Manihot escluenta) which has a lower ash content that is around 0.4 percent, has a higher starch content and mocaf also has a higher fiber content than wheat. Mocaf flour in this research as the basic ingredient of making pempek. Pempek is a snack food made from ground corn, tapioca, salt, and water. This study aims to determine the acceptance (texture, color, flavour, taste) and to know the nutrients of energy and macro nutrients in pempek mocaf. The materials used in making pempek are mocaf flour, tapioca flour, anchovy, palm oil, carrot, garlic, salt, and water. Treatment in this research pempekis F1 flour mocaf 100\%, F2 mocaf flour 75\% and tapioca flour 25\%, while F3 uses 50\% mocaf flour and 50\% tapioca flour. The method ofresearch is pempek in organoleptic test by 40 panelis then pempek most preferred analyzed nutrient energy and macro nutrient. The method of nutrient analysis used for the protein test using Kjeldahl, fat using hydrolysis-soxhlet, and carbohydrates using Luff scrhool. From the results of one way anova pempek one of the most preferred is pempek with 50 mocaf F3 flour treatment and 50\% tapioca flour. There is a marked difference to texture and taste and there is no significant difference in color and flavour. While after the analysis obtained energy 173.61 calories, 5.27 grams of protein, 4.81 grams of fat, and carbohydrates 27.31 grams. From this study it can be concluded that F3 treatment contains energy, protein and fat higher than pempek which is often circulated, while carbohydrate is lower than pempek that often circulate. Suggestion for further investigators can examine more about micro nutrient found in pempek made from mocaf flour.
\end{abstract}

\section{Keywords: Mocaf Flour, Pempek, Energy and Macro Nutrition}

\begin{abstract}
Abstrak :Tepung mocaf merupakan tepung berbahan baku umbi singkong (Manihot escluenta)yang memiliki kadar abu yang lebih rendah yaitu berkisar 0,4 persen, memiliki kadar pati yang lebih tinggi dan mocaf juga memiliki kadar serat yang lebih tinggi dibandingkan dengan terigu. Tepung mocafdalam penelitian ini sebagai bahan dasar pembuatan pempek. Penelitian ini bertujuan mengetahui daya terima (tekstur, warna, aroma, rasa) dan mengetahui zat gizi energi dan zat gizi makro pada pempek mocaf .Bahan-bahan yang digunakan dalam pembuatan pempek adalahtepung mocaf, tepung tapioka, ikan teri, minyak kelapa sawit, wortel, bawang putih, garam,dan air. Perlakuan pempek dalam penelitian ini yaitu F1 tepung mocaf $100 \%$, F2 tepung mocaf $75 \%$ dan tepung tapioka 25\%, sedangkan F3 menggunakan tepung mocaf 50\% dan tepung tapioka 50\%. Metode penelitian adalah pempek di uji organoleptic kan oleh 40 panelis lalu pempek yang paling disukai dianalisis zat gizi energi dan zat gizi makro.Metode analisis zat gizi yang digunakan untuk pengujian protein yaiu menggunakan Kjeldahl, lemak menggunakan hidrolisis-soxhlet, dan karbohidrat menggunakan Luff school.Dari hasil uji one way anova pempek yang paling disukai yaitu pempek dengan perlakuan F3 tepung mocaf 50\% dan tepung tapioka 50\%. Ada perbedaan yang nyata adalah terhadap tekstur dan rasa dan tidak terdapat perbedaan yang nyata terhadap warna dan aroma. Sedangkan setelah di analisisdidapatkan energi 173,61 kalori, protein 5,27 gram, lemak 4,81 gram, dan karbohidrat 27,31 gram. Kesimpulan perlakuan F3 mengandung energy, protein dan lemak lebih tinggi dibandingkan dengan pempek yang sering beredar, sedangkan karbohidrat lebih rendah dibandingkan dengan pempek yang sering beredar.Saran untuk peneliti selanjutnya dapat meneliti lebih lanjut mengenai zat gizi mikro yang terdapat pada pempek berbahan dasar tepung mocaf.
\end{abstract}

Kata kunci :Tepung Mocaf, Pempek, Energi dan Zat Gizi Makro 
Makanan merupakan hal yang pentingdalam pemenuhan kebutuhan masyarakat, karena makanan dapat mengganjal rasa lapar, namun masyarakat sering mengabaikan zat gizi dalam makanan tersebut khususnya kalangan remaja yang jauh dari orang tua.Mereka lebih mengutamakan cita rasa dibandingkan zat gizinya. Makanan itu biasanya terdapat pada makanan snackyang mempunyai rasa yang enak.

Salah satu makanan snack yang disukai dan biasa dikonsumsi oleh kalangan anakanak sampai masyarakat dewasa, yaitu pempek. Pempek merupakan makanan snack yang terbuat dari bahan dasar ikan giling, tepung tapioka, garam, dan air yang dicampur menjadi satu adonan dan dibentuk, lalu direbus atau bisa dikukus, lalu digoreng ataupun dipanggang yang kemudian dimakan dengan cuka(Afriani et all, 2015).Pempek juga bisa dibuat menggunakan tepung mocaf yang dapat memperkaya nilai gizi pempek.

Tepung mocaf merupakan tepung berbahan baku umbi singkong (Manihot escluenta) yang sama seperti tepung tapioka, akan tetapi tepung mocaf terbentuk karena adanya proses fermentasi bakteri penghasil asam laktat. Salah satu keunggulan tepung mocaf memiliki kadar abu yang lebih rendah yaitu berkisar 0,4 persen, memiliki kadar pati yang lebih tinggi dan mocaf juga memiliki kadar serat yang lebih tinggi dibandingkan dengan terigu (Widasari danHandayani, 2014)

Berdasarkan Tabel Komposisi Pangan Indonesia (TKPI) 2009 mengenai zat gizi bahan makanan per 100 gram untuk bahan makanan pempek kapal selam mengandung energi 152 kalori, protein 4,5 gram, lemak 2,3 gram, dan karbohidrat 28,2 gram, dan pempek telur mengandung energi 156 kalori, protein 4,7 gram, lemak 2,7 gram, dankarbohidrat 28,3 gram(Mahmud dan zulfianto, 2009). Banyak pempek yang beredar dengan komposisi bahan baku yang berbeda-beda, oleh karena itupeneliti tertarik untuk mengetahui daya terima (tekstur, warna, aroma, rasa) dan analisis zat gizi energi dan zat gizi makro pada pempek mocaf.

\section{BAHAN DAN CARA KERJA}

Bahan utama yang digunakan dalam penelitian adalah tepung mocaf, sedangkan bahan tambahannya digunakan tepung tapioka, ikan teri, bawang putih, wortel, minyak kelapa sawit, garam, air dan telur. Alat yang digunakan dalam proses pengolahan pempek yaitu baskom, panci, wajan, pisau, timbangan, kompor, talenan, serbet, centong nasi, sendok. Metode yang digunakan adalah Rancangan Acak Lengkap dengan 3 perlakuan yaitu F1, F2 dan F3.

F1 : Pempek dengan tepung mocaf $100 \%$

F2 : Pempek dengan tepung mocaf $75 \%$ dan tepung tapioka $25 \%$

F3 : Pempek dengan tepung mocaf 50\% dan tepung tapioka $50 \%$

Berdasarkan hasil perhitungan Tabel Komposisi Pangan Indonesia (TKPI 2009) zat gizi pada perlakuan F1 yaitu 276,7 kalori, protein 5,93 gram, lemak 8,33 gram, karbohidrat 45,31 gram. Perlakuan F2 yaitu 279,4 kalori, protein 5,84 gram, lemak 8,37 gram, karbohidrat 45,64 gram, sedangkan F3 yaitu 282,3 kalori, protein 5,75 gram, lemak 8,3 gram, karbohidrat 45,98 gram per 100 gram (1 porsi snack).

\section{HASIL}

Daya terima dilakukan oleh 40 panelis terhadap pempek mocaf. Pengujian organoleptik mulai dari yang sangat tidak disukai diberikan skor 0, tidak sukadiberikan skor 1, agak sukadiberikan skor 2, suka diberikan skor 3 hingga yang sangat disukaidiberikan skor 4 yang meliputi tekstur, warna, aroma, rasa.

\section{Daya terima tekstur}

Hasil uji organoleptik oleh 40 orang, diketahui bahwa sebanyak 20 orang panelis memberikan penilaian suka (skor 3) untuk 
tekstur pada pempek mocaf pada perlakuan F2 dapat dilihat pada Gambar 1.

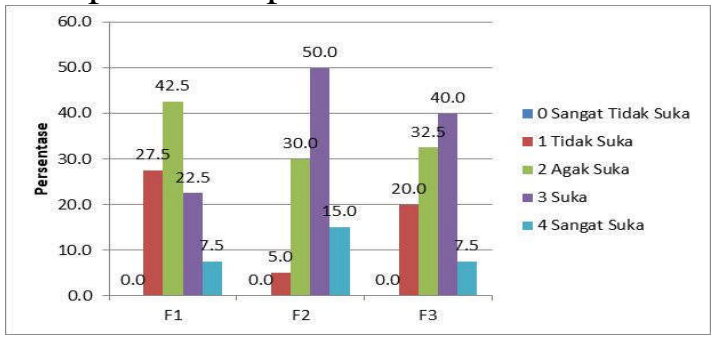

Gambar 1 Hasil uji organoleptik tekstur pada pempek mocaf

Hasil penelitian diketahui bahwapempek mocaf pada pengujian organoleptik tekstur yang paling tinggi tingkat kesukaannya yaitu F2 tepung mocaf $75 \%$ dan tepung tapioka $25 \%$ dengan kategori suka sebanyak 20 orang, dibandingkan dengan F1 sebanyak 17 orang dikategori agak suka dan F3 sebanyak 16 orang dikategori suka.

Tabel 1 Daya Terima Tekstur Pempek Mocaf Dengan

\begin{tabular}{lclll} 
& Variasi & \multicolumn{2}{l}{ Pengolahan } & \\
\hline Parameter & Produk & $\begin{array}{l}\text { Nilai } \\
\text { rerata } \pm \\
\text { SD }\end{array}$ & F & Sig \\
& & & \\
\hline Tekstur & F1 & $2,10 \pm$ & 5,836 & 0,00 \\
& & 0,900 & & 4 \\
& F2 & $2,75 \pm$ & & \\
& & 0,776 & & \\
& F3 & $2,35 \pm$ & & \\
& & 0,893 & & \\
& &
\end{tabular}

Berdasarkan hasil uji statistik anova terhadap tekstur dari variasi pengolahan pempek mocaf didapatkan hasil bahwa probabilitas $\mathrm{F}$ dihitung pengolahan adalah 5,836 dan hasil $\mathrm{p}$ value $0,004(\mathrm{p}>0,05)$ yang berarti variasi pengolahan pempek mocaf memiliki perbedaan yang signifikan terhadap tekstur pempek dari berbagai variasi pengolahan.

\section{Daya terima warna}

Hasil uji organoleptik oleh 40 orang, diketahui bahwa sebanyak 25 orang panelis memberikan penilaian suka (skor 3) untuk warna pada pempek mocaf pada perlakuan F1 dapat dilihat pada Gambar 2.

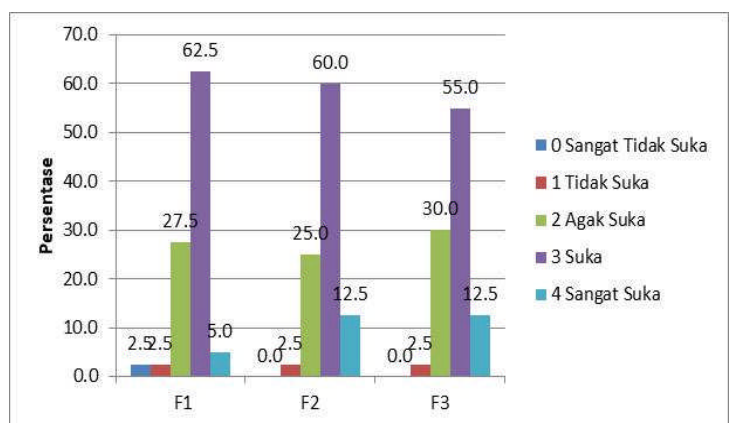

Gambar 2 Hasil uji organoleptik warna pada pempek mocaf

Pengujian organoleptik warna yang paling tinggi tingkat kesukaannya yaitu F1 tepung mocaf $100 \%$ dengan kategori suka sebanyak 25 orang, sedangkan F2 sebanyak 24 orang dikategori suka dan F3 sebanyak 22 orang dikategori suka.

Tabel 2 Daya Terima Warna Pempek Mocaf Dengan Variasi Pengolahan

\begin{tabular}{lcccc}
\hline Parameter & Produk & $\begin{array}{c}\text { Nilai } \\
\text { rerata } \pm \\
\text { SD }\end{array}$ & F & Sig \\
& & & & \\
\hline Warna & F1 & $2,65 \pm$ & 657 & 0,520 \\
& & 0,736 & & \\
& F2 & $2,82 \pm$ & & \\
& & 0,675 & & \\
& F3 & $2,78 \pm$ & & \\
& & 0,698 & & \\
& & &
\end{tabular}

Berdasarkan hasil uji statistik anova terhadap warna dari variasi pengolahan pempek mocaf didapatkan hasil bahwa probabilitas $\mathrm{F}$ dihitung pengolahan adalah 657 dan hasil $\mathrm{p}$ value $0,520(\mathrm{p}>0,05)$ yang berarti variasi pengolahan pempek mocaf tidak memiliki pengaruh yang signifikan terhadap warna pempek dari berbagai variasi pengolahan.

\section{Daya terima aroma}

Hasil uji organoleptik oleh 40 orang, diketahui bahwa sebanyak 20 orang panelis memberikan penilaian suka (skor 3) untuk aroma pada pempek mocaf pada perlakuan F3 dapat dilihat pada Gambar 4.3. 


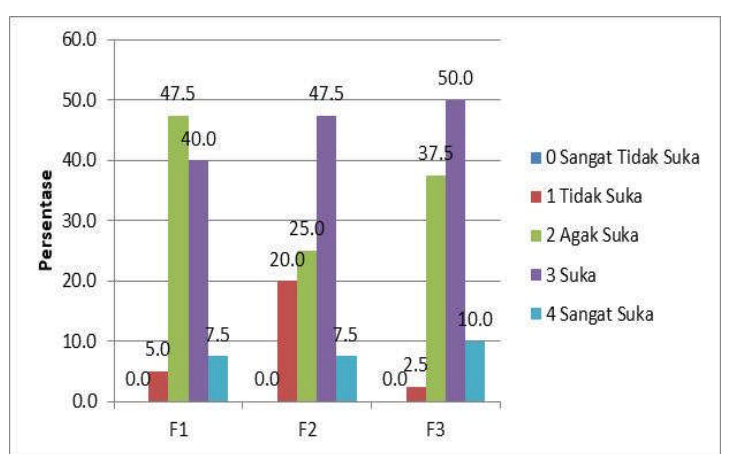

Gambar 3 Hasil uji organoleptik aroma pada pempek mocaf

Pengujian organoleptik aroma yang paling tinggi tingkat kesukaannya yaitu F3 dengan kategori suka sebanyak 20 orang, sedangkan F2 sebanyak 19 orang dikategori suka dan F1 sebanyak 19 orang dikategori agak suka.

Tabel 4 daya terima aroma pempek mocaf dengan variasi pengolahan

\begin{tabular}{ccccc}
\hline Parameter & Produk & $\begin{array}{l}\text { Nilai } \\
\text { rerata } \pm \\
\text { SD }\end{array}$ & F & Sig \\
\hline Aroma & F1 & $\begin{array}{c}2,50 \pm \\
0,716\end{array}$ & 1,092 & 0,339 \\
& & & & \\
& F2 & $2,42 \pm$ & & \\
& & 0,903 & & \\
& F3 & $2,68 \pm$ & & \\
& & 0,694 & &
\end{tabular}

Berdasarkan hasil uji statistik anova terhadap aroma dari variasi pengolahan pempek mocaf didapatkan hasil bahwa probabilitas $\mathrm{F}$ dihitung pengolahan adalah 1,092 dan hasil $\mathrm{p}$ value $0,339(\mathrm{p}>0,05)$ yang berarti variasi pengolahan pempek mocaf tidak memiliki pengaruh yang signifikan terhadap aroma pempek dari berbagai variasi pengolahan.

\section{Daya terima rasa}

Hasil uji organoleptik oleh 40 orang, diketahui bahwa sebanyak 23 orang panelis memberikan penilaian agak suka (skor 2) untuk tekstur pada pempek mocaf pada perlakuan F1 dapat dilihat pada Gambar 4.

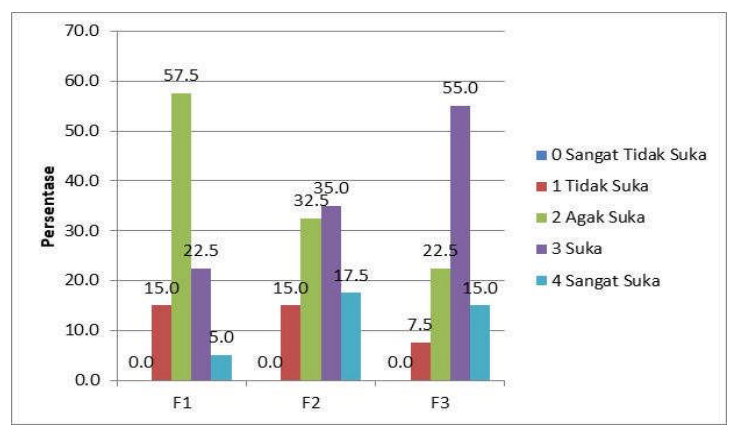

Gambar 4 Hasil uji organoleptik rasa pada pempek mocaf

Sedangkan pengujian organoleptik rasa yang paling tinggi tingkat kesukaannya yaitu F1 dengan kategori agak suka sebanyak 23 orang, sedangkan F3 sebanyak 22 orang dikategori suka dan F2 sebanyak 14 orang dikategori suka.

Tabel 4 daya terima rasa pempek mocaf dengan variasi pengolahan

\begin{tabular}{ccccc}
\hline Parameter & Produk & $\begin{array}{l}\text { Nilai } \\
\text { rerata } \pm \\
\text { SD }\end{array}$ & F & Sig \\
& & & & \\
\hline Rasa & F1 & $\begin{array}{c}2,18 \pm \\
0,747\end{array}$ & 5,202 & 0,007 \\
& & & & \\
& F2 & $2,55 \pm$ & & \\
& & 0,959 & & \\
& F3 & $2,78 \pm$ & & \\
& & 0,800 & & \\
& & & \\
\hline
\end{tabular}

Berdasarkan hasil uji statistik anova terhadap rasa dari variasi pengolahan pempek mocaf didapatkan hasil bahwa probabilitas $\mathrm{F}$ dihitung pengolahan adalah $5,202$ dan hasil $\mathrm{p}$ value 0,007 ( $\mathrm{p}<0,05)$ yang berarti variasi pengolahan pempek mocaf memiliki perbedaan yang signifikan terhadap rasa pempek dari berbagai variasi pengolahan.

\section{Kandungan zat gizi}

Berdasarkan hasil uji organoleptik didapatkan bahwa yang paling banyak disukai yaitu perlakuan F3 dengan komposisi tepung mocaf $50 \%$ dan tepung tapioka 50\%. Maka yang dianalisis yaitu dengan perlakuan F3 dengan tepung mocaf $50 \%$ dan tepung tapioka $50 \%$ dan didapatkan hasil analisis zat gizi energi 
pada pempek mocaf yaitu sebesar 173,61 kal, protein 5,37 gram, lemak 4,81 gram, dan karbohidrat 27,31 gram per 100 gram (porsi snack).

Tabel Kandungan gizi pempek per 100 gram

\begin{tabular}{lcc}
\hline \multicolumn{1}{c}{ Kandungan gizi } & $\begin{array}{c}\text { Pempek } \\
\text { mocaf }\end{array}$ & Satuan \\
\hline Energi & 173,61 & Kal \\
Protein & 5,37 & Gram \\
Lemak & 4,81 & Gram \\
Karbohidrat & 27,31 & Gram \\
\hline
\end{tabular}

\section{PEMBAHASAN}

Menurut Rochima 2015, perubahan tekstur suatu bahan dapat merubah aroma dan rasanya.Tekstur merupakan salah satu parameter penting dalam menentukan mutu makanan.Komponen terbesar dari tepung adalah pati yang merupakan polisakarida dari karbohidrat.Hidrat arang dalam tepung (pati) dapat memudahkan pemberian bentuk pada makanan.Karbohidrat dari golongan pati ini bersifat sangat menyerap air. Pada saat dipanaskan, tepung akan menyerap air dan mengalami gelatinisasi. Adanya gelatinisasi ini tepung memperkuat struktur gel pada produk (Dwijaya dkk, 2015).

Hasil penelitian yang telah dilakukan dari ketiga pempek diketahui bahwa pempek mocaf pada pengujian organoleptik tekstur yang paling tinggi tingkat kesukaannya yaitu F2 yang memiliki komposisi tepung mocaf $75 \%$ dan tepung tapioka $25 \%$ dengan kategori suka sebanyak 20 orang. Hal ini dikarenakan pada tekstur produk olahan tepung mocaf lebih lunak bila dibandingkan tepung singkong biasa dan terigu.

Hasil uji menggunakan One Way Anova daya terima tekstur ini secara nyata ada perbedaan yang nyata karena $\mathrm{F}$ hitung adalah 5,836 dan hasil $\mathrm{p}$ value 0,004 (p > $0,05)$. Perbedaan tekstur ini karena tekstur yang dimiliki pada tepung mocaf memilki tekstur yang lembut.

Penggunaan warna dapat digunakan sebagai indikator kesegaran atau kematangan, baik tidaknya cara pencampuran atau cara pengolahan dapat ditandai dengan warna yang seragam dan merata. Daya tarik makanan sangat dipengaruhi oleh penampilan seperti warna.Hal ini merupakan salah satu faktor fisik yang menuntun dan menggugah selera orang untuk memilih makanan (Kamsina, 2012).

Hasil penelitian yang telah dilakukan dari ketiga pempek diketahui bahwa pempek mocaf pada pengujian organoleptik warna yang paling tinggi tingkat kesukaannya yaitu F1 dengan komposisi $100 \%$ tepung mocaf dengan kategori suka sebanyak 25 orang. Hal ini dikarenakan pada tepung mocaf (Modified Cassava Flour) merupakan produk tepung dari ubi kayu yang diproses dengan menggunakan prinsip memodifikasi sel ubi kayu secara fermentasi, sehingga hasilnya berbeda dengan tepung gaplek maupun tepung ubi kayu.Mikroba yang tumbuh menghasilkan enzim pektinolitik dan sellulolitik yang dapat menghancurkan dinding sel singkong, sehingga terjadi liberasi granula pati.Mikroba tersebut juga menghasilkan enzim - enzim yang menghidrolisis pati menjadi gula dan selanjutnya mengubahnya menjadi asam asam organik, terutama asam laktat. Hal ini akan menyebabkan perubahan karakteristik dari tepung yang dihasilkan. Tepung mocaf memiliki keunggulan dibandingkan dengan tepung ubi kayu biasa yaitu warna tepung lebih putih yang mempunyai derajat putih antara 68,48 hingga 76,4 . Derajat putih tepung mocaf disebabkan karena selama proses fermentasi terjadi penghilangan komponen penimbul warna dan protein yang dapat menyebabkan warna coklat ketika pengeringan.

Secara statistik yang diuji menggunakan One Way Anova terhadap 
daya terima warna ini secara nyata tidak ada perbedaan yang nyata karena $F$ dihitung pengolahan adalah 657 dan hasil $p$ value $0,520(\mathrm{p}>0,05)$.

Aroma atau flavour dalam makanan sangat dipengaruhi oleh jumlah bahan yang digunakan dan proses pengolahannya. Makanan yang memiliki aroma sedap dan khas akan mengundang selera konsumennya sebagai pembangkit selera seseorang (Kamsina, 2012).

Hasil penelitian yang telah dilakukan dari ketiga pempek diketahui bahwa pempek mocaf pada pengujian organoleptik aroma yang paling tinggi tingkat kesukaannya yaitu F3 dengan komposisi $50 \%$ tepung mocaf dan $50 \%$ tepung tapioka dengan kategori suka sebanyak 20 orang. Hal ini dikarenakan pada tepung mocaf yang digunakan sebagai bahan substitusi tepung terigu telah mengalami proses fermentasi sehingga aroma singkong pada tepung mocaf sudah menghilang dan mengubah sifat kekentalan dan elastisitas dalam pembuatan adonan yang tidaklah sama persis dengan tepung terigu.Namun demikian tingkat penerimaan dan jumlah panelis terhadap aroma pempek mocaf pada perlakuan F1, F2 dan F3 dengan uji One Way Anova tidak memberikan perbeadaan yang nyata karena $\mathrm{F}$ hitung 1,092 dan hasil $p$ value $0,339(\mathrm{p}>0,05)$.

Rasa merupakan faktor yang menentukan dalam pengambilan keputusan panelis atau konsumen selain aroma dan warnanya. Rasa suatu pangan dapat berasal dari sifat bahan baku itu sendiri atau berasal dari penambahan zat lain pada proses pengolahannya (Ayustaningwarno, 2014). Rasa suatu produk mempengaruhi tingkat penerimaan konsumen. Meskipun parameter lainnya baik, jika rasanya tidak disukai maka produk tersebut akan ditolak. Hasil penelitian yang telah dilakukan dari ketiga pempek diketahui bahwa pempek mocaf pada pengujian organoleptik rasa yang paling tinggi tingkat kesukaannya yaitu F1 dengan komposisi $100 \%$ tepung mocaf dengan kategori suka sebanyak 23 orang. Hal ini dikarenakan proses fermentasi singkong menyebabkan perubahan karakteristik tepung yang dihasilkan sehingga menyebabkan naiknya viskositas, daya rehidrasi, dan kemudahan melarut dan cita rasa tepung mocaf menjadi netral dengan menutupi cita rasa singkong sampai $70 \%$ serta memiliki karakteristik mirip terigu sehingga dapat digunakan sebagai pengganti terigu atau campuran terigu.

Berdasarkan hasil statistik uji One Way Anova rasa dari variasi pengolahan pempek mocaf didapatkan hasil bahwa $\mathrm{F}$ dihitung pengolahan adalah 5,202 dan hasil $\mathrm{p}$ value $0,007(\mathrm{p}<0,05)$ yang berarti variasi pengolahan pempek mocaf memiliki perbedaan yang signifikan terhadap rasa pempek dari berbagai variasi pengolahan. Perbedaan rasa ini dikarenakan adanya perbedaan komposisi bahan dasar yang ada pada pembuatan pempek mocaf.

Energi merupakan suatu proses oksidasi yang didapatkan dari protein, lemak dan karbohidrat (Beck, 2011). Berdasarkan hasil uji organoleptik didapatkan bahwa yang paling banyak disukai yaitu perlakuan F3 tepung mocaf $50 \%$ dengan tepung tapioka 50\%. Maka yang dianalisis yaitu dengan perlakuan F3 tepung mocaf 50\% dan tepung atpioka $50 \%$ didapatkan hasil energi sebesar 173,61 kalori. Sedangkan perhitungan energi dengan menggunakan Daftar Komposisi Bahan Makanan pada perlakuan F3 yaitu sebesar 283,2 gram.Berdasarkan hasil penelitian perbandingan pempek mocaf lebih tinggi kandungan energinya dibandingkan dengan pempek yang sudah beredar. Pempek mocaf memiliki kandungan energi sebesar 173,61 kalori, sedangkan pempek kapal selam memiliki kandungan energi 152 kalori dan pempek telur memiliki kandungan energi 156 kalori. Tingginya kandungan zat gizi energi pada pempek mocaf dikarenakan pada tepung mocaf 
memiliki kandungan zat gizi energi sebesar 358 kalori per 100 gram sedangkan tepung sagu memiliki kandungan zat gizi energi sebesar 355 kalori per 100 gram.

Berdasarkan hasil uji organoleptik didapatkan bahwa yang paling banyak disukai yaitu perlakuan F3 tepung mocaf $50 \%$ dengan tepung tapioka 50\%. Maka yang dianalisis yaitu dengan perlakuan F3 tepung mocaf $50 \%$ dengan tepung tapioka $50 \%$ didapatkan hasil protein sebesar 5,27 gram. Sedangkan perhitungan protein dengan menggunakan Daftar Komposisi Bahan Makanan pada perlakuan F3 yaitu sebesar 5,75 gram.Protein pada pempek berperan dalam pembentukan gel, terutama protein myofibril yang merupakan bagian terbesar dalam protein ikan sebagai bahan baku pembuatan pempek. Protein ini terdiri dari miosin, aktin, serta protein regulasi yaitu gabungan dari aktin dan miosin yang membentuk aktomiosin (Dwijaya dkk, 2015).Berdasarkan hasil penelitian perbandingan pempek mocaf lebih tinggi kandungan proteinnya dibandingkan dengan pempek yang sudah beredar. Pempek mocaf memiliki kandungan gizi protein sebesar 5,27 gram, sedangkan pempek kapal selam memiliki kandungan protein 4,5 gram dan pempek telur memiliki kandungan protein 4,7 gram. Tingginya kandungan zat gizi protein pada pempek mocaf disebabkan protein yang terkandung didalam ikan teri sebesar 33,4 gram dan protein yang terkandung didalam tepung mocaf sebesar 1,0 gram sedangkan tepung tapioka memiliki kandungan gizi protein sebesar 1,1 gram.

Lemak adalah komponen makanan yang tidak larut dalam air. Lemak berperan sangat penting dalam gizi manusia karena merupakan sumber energi, dengan dapat memperbaiki citarasa, tekstur dan sebagai sumber vitamin A, D, E dan K (Sihab, 2017). Berdasarkan hasil uji organoleptik didapatkan bahwa yang paling banyak disukai yaitu perlakuan F3 tepung mocaf $50 \%$ dengan tepung tapioka 50\%. Maka yang dianalisis yaitu dengan perlakuan F3 tepung mocaf 50\% dengan tepung tapioka $50 \%$ didapatkan hasil lemak sebesar 4,81 gram. Sedangkan perhitungan energi dengan menggunakan Daftar Komposisi Bahan Makanan pada perlakuan F3 yaitu sebesar 8,3 gram.

$$
\text { Menurut Dwijaya }
$$

penggunaan ikan yang semakin banyak akan meningkatkan kadar lemak dan protein pada pempek. Selain itu, penambahan minyak pada proses pengadonan dalam pembuatan pempek akan mempengaruhi lemak yang dihasilkan pada produk.Berdasarkan hasil penelitian perbandingan pempek mocaf lebih tinggi kandungan lemaknya dibandingkan dengan pempek yang sudah beredar. Pempek mocaf memiliki kandungan zat gizi lemak sebesar 4,81 gram, sedangkan pempek kapal selam memiliki kandungan zat gizi lemak 2,3 gram dan pempek telur memiliki kandungan lemak 2,7 gram. Hal ini dikarenakan kandungan gizi tepung mocaf 0,4 gram, sedangkan lemak tepung tapioka mengandung lemak 0,5 gram.

Karbohidrat mempunyai peranan yang penting dalam menentukan karakteristik bahan makanan dan dapat mempengaruhi rasa, warna dan tekstur produk (Dwijaya dkk, 2015). Berdasarkan hasil uji organoleptik didapatkan bahwa yang paling banyak disukai yaitu perlakuan F3 tepung mocaf 50\% dengan tepung tapioka 50\%. Maka yang dianalisis yaitu dengan perlakuan F3 tepung mocaf 50\% dengan tepung tapioka $50 \%$ didapatkan hasil karbohidrat sebesar 27,31 gram. Sedangkan perhitungan lemak dengan menggunakan Daftar Komposisi Bahan Makanan pada perlakuan F3 tepung mocaf $50 \%$ dengan tepung tapioka $50 \%$ yaitu sebesar 45,98 gram.

Berdasarkan hasil penelitian perbandingan pempek mocaf lebih rendah kandungan karbohidratnya dibandingkan dengan pempek yang sudah beredar. Pempek mocaf memiliki kandungan zat gizi karbohidrat sebesar 27,31 gram, sedangkan pempek kapal selam memiliki 
kandungan karbohidrat sebesar 28,2 gram dan pempek telur memiliki kandungan karbohidrat sebesar 28,3 gram. Hal inidikarenakan pada tepung mocaf memiliki kandungan zat gizi karbohidrat sebesar 88,6 gram per 100 gram sedangkan tepung tapioka memiliki kandungan zat gizi karbohidrat sebesar 88,2 per 100 gram.

\section{KESIMPULAN}

Hasil penelitian ini dapat disimpulkan bahwa dari segi organoleptik tekstur, warna, aroma, dan rasa, didapatkan dari ke tiga perlakuan F1 tepung mocaf $100 \%$, F2tepung mocaf $75 \%$ dan tepung tapioka $25 \%$, dan F3 tepung mocaf $50 \%$ dan tepung tapioka $50 \%$.Yang paling banyak

\section{DAFTAR RUJUKAN}

Afriani, Y., Lestari, S. (2015). Karakteristik FisikoKimia dan Sensori Pempek Ikan Gabus ( Channa striata) dengan Penambahan Brokoli ( Brassica oleracea ) sebagai Pangan Fungsional, 4(2), 95-103.

Beck, M. 2011.Ilmu Gizi Dan Diet Hubungannya Dengan Penyakit-Penyakit Untuk Perawat Dan Dokter. Yayasan Essentia Medica : Yogyakarta

Dwijaya, Susi Lestari*) SH. Karakteristik Mutu Kimia Pempek dan Potensi Cemaran Logam Berat ( $\mathrm{Pb}$ dan $\mathrm{Cd}$ ) di Kota Palembang. 2015;4(1):57-66.

Falahudin, I., Pane, E. R., \& Kurniati, N. (2016). Uji Kandungan Boraks Pada Pempek Lenjer disukai yaitu perlakuan F3 dengan komposisi tepung mocaf $50 \%$ dan tepung tapioka 50\%. Setelah itu pempek mocaf dianalisis zat gizinya dan didapatkan energi sebesar 173,61 kalori, protein sebesar 5,27 gram, lemak sebesar 4,81 gram, karbohidrat sebesar 27,31 gram.

Saran untuk pembuatan selanjutnya dapat mengevaluasi teknik pengolahan yang paling baik seperti dikukus agar dapat mempertahan zat gizi pada pempek yang berbahan dasar tepung mocaf dan untuk peneliti selanjutnya dapat meneliti lebih lanjut mengenai zat gizi mikro yang terdapat pada pempek berbahan dasar tepung mocaf.

yang dijual di Kelurahan Pahlawan.Jurnal Biota, 2(2), 143-150.

Sihab1)*, La Karimuna1) T. Dengan Penambahan Maltodekstrin Terhadap Penilaian Organoleptik Bayam Dan Kandungan Gizi Keripik ( Amaranthus Spp ). 2017;2(3):575589.

Mahmud, Mien.K dan Zulfianto, N.A. 2009. Tabel Komposisi Pangan Indonesia. Elex Media Komputindo : Jakarta

Widasari S. Pengaruh Proporsi Terigu - Mocaf ( Modified Cassava Flour ) Dan Penambahan Tepung Formula Tempe Terhadap Hasil Jadi Flake .2014 ; 3:222-228. 